\title{
Isolated Soy Protein-Based Diet Ameliorates Glycemia and Antioxidants Enzyme Activities in Streptozotocin-Induced Diabetes
}

\author{
Roberta Hack Mendes ${ }^{1,2 *}$, Martine Kienzle Hagen 1,3, Jaqueline Barp, Erna Vogt de Jong4, \\ Júlia Dubois Moreira5 ${ }^{5}$, Álvaro Reischak-Oliveira', Maria Cláudia Irigoyen ${ }^{1,7}$, \\ Adriane Belló-Klein ${ }^{1}$ \\ ${ }^{1}$ Physiology Departament, Federal University of Rio Grande do Sul, Porto Alegre, Brazil \\ ${ }^{2}$ Institute of Nutrition Josué de Castro, Rio de Janeiro Federal University, Rio de Janeiro, Brazil \\ ${ }^{3}$ Department of Internal Medicine, Federal University of Rio Grande do Sul, Porto Alegre, Brazil \\ ${ }^{4}$ Institute of Food Science and Technology, Federal University of Rio Grande do Sul, Porto Alegre, Brazil \\ ${ }^{5}$ Department of Nutrition, Health Sciences Centre, Federal University of Santa Catarina, Florianópolis, Brazil \\ ${ }^{6}$ School of Physical Education, Federal University of Rio Grande do Sul, Porto Alegre, Brazil \\ ${ }^{7}$ Hypertension Unit, Heart Institute, Federal University of São Paulo, São Paulo, Brazil \\ Email: nutribeta@hotmail.com, martine.kienzle@hagen.net, jaquelinebarp@hotmail.com, \\ juliamoreira@gmail.com, hipirigoyen@gmail.com, belklein@ufrgs.br
}

Received 30 August 2014; revised 20 September 2014; accepted 8 October 2014

Copyright (C) 2014 by authors and Scientific Research Publishing Inc.

This work is licensed under the Creative Commons Attribution International License (CC BY).

http://creativecommons.org/licenses/by/4.0/

(c) (†) Open Access

\section{Abstract}

The objective of this study was to evaluate the changes induced by isolated soy protein (ISP)-based diet on glycemia and oxidative stress biomarkers in diabetic rats. Fifteen male Wistar rats $(35 \pm 4$ g, aged 21 days) were assigned to three groups: Casein ( $C$ group), which received casein-based diet during experimental protocol; Diabetic treated with Casein (D + C group) that received caseinbased diet before and after diabetes induction; Diabetic treated with ISP (D + S group) that received casein-based diet before diabetes induction and after received ISP-based diet for the experimental protocol. Diabetes was induced by a single dose of streptozotocin $(50 \mathrm{mg} / \mathrm{kg}$ body weight i.v.). After three weeks of dietary treatment, total nitrates, lipid peroxidation, antioxidant enzyme activities of superoxide dismutase (SOD), catalase (CAT), glutathione-S-transferase (GST) were measured in heart homogenates. ISP-based diet promoted an improvement in the glycemic levels of diabetic rats compared with casein-based diet (362 \pm 25 vs $461 \pm 30 \mathrm{mg} / \mathrm{dL})$. CAT activity demonstrated a significant decrease in $D+C$ and $D+S$ groups. $D+S$ group presented a significant in-

"Corresponding author.

How to cite this paper: Mendes, R.H., Hagen, M.K., Barp, J., de Jong, E.V., Moreira, J.D., Reischak-Oliveira, Á., Irigoyen, M.C. and Belló-Klein, A. (2014) Isolated Soy Protein-Based Diet Ameliorates Glycemia and Antioxidants Enzyme Activities in Streptozotocin-Induced Diabetes. Food and Nutrition Sciences, 5, 2089-2096. http://dx.doi.org/10.4236/fns.2014.521221 
crease in SOD and GST activities. Lipid peroxidation was not different among experimental groups. The overall results suggested the potential benefits of ISP-based diet consumption to improve the life quality of diabetic patients.

\title{
Keywords
}

\author{
Isolated Soy Protein, Diabetes, Oxidative Stress
}

\section{Introduction}

Diabetes mellitus (DM) is a chronic disease of epidemic proportion being a major public health problem in the world. In the United States, patients with diabetes spend an average of 6.000US\$ on medical costs to treat this disease. It is very important the inclusion of strategies using natural products to prevent and treat DM [1]. DM is characterized by relative or absolute deficiency of insulin secretion and/or insulin resistance that causes chronic hyperglycemia and impaired carbohydrates, lipids and proteins metabolism [2]. Hyperglycemia is an important predictor of metabolic abnormalities, it is may be caused by polyol formation, activation of kinase protein C, advanced glycation end products, and hexosamine formation [3] [4].

During hyperglycemia and its metabolic abnormalities, the diet balance, mainly about protein quality to protect against diabetes complications. Moreover, nutritional counseling is important for protecting diabetics patients against reactive oxygen species (ROS) production and modulate antioxidants defenses, such as superoxide radical $\left(\mathrm{NO}_{2}^{-}\right)$, hydrogen peroxide $\left(\mathrm{H}_{2} \mathrm{O}_{2}\right)$, and hydroxyl radical $\left(\mathrm{OH}^{*}\right)$, preventing oxidative stress and the development and progression of diabetes [5].

Antioxidants have been investigated in relation to the treatment of diabetes and its complications, such as the cardiovascular disease [6] [7]. The generation of ROS and reactive nitrogen species (RNS) inducing oxidative and nitrosative stress is related to cellular dysfunction and death in cardiomyopathy [8]. Flavonoids are one of the group of compounds that has been highly considered in recent years as polyphenolic compounds that are able to prevent oxidative injury by several mechanisms, such as ROS scavenging, protecting against chelating metal ions [9]-[11].

Soybean contains phytoestrogen (isoflavones), which are plant components that interact with mammalian endocrine systems. Furthermore, soybean products are good source of high-quality amino acids, contains no cholesterol, is low in saturated fat and it has been shown to reduce glycemia, to ameliorate glucose tolerance and insulin tests. In 2000, the American Heart Association (AHA) Nutrition Committee concluded that it is prudent to recommend including soy protein foods in a diet low in saturated fat and cholesterol [12]. Beneficial effects of soybean were demonstrated in many studies where soybean consumption prevented against some types of cancer, reduced risk of osteoporosis, ameliorated chronic renal disease, exhibited anti-atherosclerotic activity, and decreased the risk of coronary disease [13] [14].

The soybean mechanisms of action for cardiovascular system protection are associated with the antioxidant properties of genistein, daidzein, and the synergetic action of both mentioned molecules [15]. Genistein is the most abundant isoflavone and may exert its effects via mechanism such as modulation of cell signalling pathways and effects on gene expression [16]. Moreover, in vitro studies have suggested the hydrogen-donating ability and the inhibition of lipid peroxidation by isoflavones and their metabolites [15] [17].

Nowadays, there are a wide variety of soy products available for consumption, therefore is necessary to known about differences among the products and their effects. Isolated soy is $92.2 \%$ protein, while the soybean hypocotyl (SH) is $42.6 \%$ protein, $43.4 \%$ carbohydrates and $11.4 \%$ fat [18]. The soy products with more fat content cannot be stored for much time. By the way, this ingredient is cheaper for food industry. In relation to isoflavones, it was possibly observed that SH has greater amounts of glycoside isoflavone (daidzin), where ISP daidzein and genistein are the main isoflavones [19].

This work was conducted to evaluate the effects of an isolate soy protein (ISP) diet on glycemia and oxidative stress biomarkers in heart of streptozotocin-induced diabetes rats. We tested the hypothesis that the ISP diet would promote better glycemic control in diabetic rats and provide cardioprotective effects by improving anti- 
oxidant enzymes activities in myocardium.

\section{Materials and Methods}

\subsection{Animals, Induction of Diabetes and Experimental Protocol}

Fifteen male Wistar rats with twenty one days old, weighing $35 \pm 4$ g were obtained from the Instituto de Ciências Básicas da Saúde (ICBS) of the Universidade Federal do Rio Grande do Sul (UFRGS), Porto Alegre, Brazil. All animals were housed in individual cages, received water and rat chow ad libitum, and were maintained under standard laboratory conditions (controlled temperature $21^{\circ} \mathrm{C}, 12$-hour light/dark cycle). Before the injection, rats were fasted for 10 hours [20]. Induction of diabetes was administrated to animals four weeks after the beginning of dietby a single injection of STZ (Sigma Chemical Co., St. Louis, MO, USA), $50 \mathrm{mg} / \mathrm{kg}$, in tail vein. STZ was dissolved in citrate buffer ( $\mathrm{pH}$ 4.5) and injected slowly. One week after injection, glycaemia was analyzed by the glucose oxidase method with a glycosimeter (test strips, Advantage, Roche, Brazil) in blood collected from the venous retro-orbital plexus. Rats that showed a glycemic concentration $\geq 200 \mathrm{mg} / \mathrm{dL}$ were randomized to one of the diabetic groups.

\subsection{Diets}

The diets were prepared according to AIN-G 93 [21] [22] and contained similar amounts of protein (adjusted according values of AIN-G 93 for protein using cornstarch), fat, carbohydrates, vitamins, minerals, except for the protein source: casein or ISP. The isoflavone content of ISP (analysis was performed at the Physical Chemistry Laboratory of the Empresa Brasileira de Pesquisa Agropecuária-EMBRAPA, Paraná, Brazil) was reported to be $189 \mathrm{mg} / 100 \mathrm{~g}$ of ISP; $67 \%$ of isoflavones are in aglycone form, being more easily absorbed [19].

All animals were fed with the experimental diets for three weeks and were weighed weekly throughout the study. Food intake was measured three times a week. Twenty rats were allocated into three groups ( $n=5 /$ group): 1) Casein (C), euglycemic and fed with casein-based diet; 2) Diabetic Casein (D + C), streptozotocin-diabetic rat (STZ) and fed with casein-based diet; and 3) Diabetic Soy (D + S), fed with casein-based diet before diabetic induction by STZ. Seven days after diabetes induction, glycaemia was measured, if it was $\geq 200 \mathrm{mg} / \mathrm{dL}$, rats were fed ISP. All animal procedures used in this study were in accordance with the Principles of Animal Care (COBEA-Brazilian College of Animal Experimentation.

\subsection{Tissue Homogenate Preparation}

After 3 weeks of dietary treatment, immediately following euthanasia, the hearts were removed, cleaned, and washed in ice-cold normal saline. The hearts was homogenized in $1.15 \%(\mathrm{w} / \mathrm{v})$ potassium chloride containing 1 $\mathrm{mM}$ phenylmethylsulfonyl fluoride in Ultra-Turrax. The homogenates were centrifuged at $1000 \mathrm{~g}$ for $10 \mathrm{~min}$ at $4^{\circ} \mathrm{C}$ to discard nuclei and cell debris, and the supernatant fraction obtained was frozen at $-70^{\circ} \mathrm{C}$ for further measurements [23].

\subsection{Nitric Oxide Metabolites}

Total nitrates $\left(\mathrm{NO}_{3}^{-}\right)$were determined as total nitrites (initial nitrite plus nitrite reduced from nitrate) after its reduction using nitrate reductase, from Aspergillus species. Nitrites $\left(\mathrm{NO}_{2}^{-}\right)$were determined using the Griess reagent, in which a chromophore with a strong absorbance at $540 \mathrm{~nm}$ is formed by the reaction of nitrite with a mixture of naphthyl-ethylenediamine (0.1\%) and sulphanilalamide (1\%). A standard curve was established with a set of serial dilutions $\left(10^{-8}-10^{-3} \mathrm{~mol} / \mathrm{L}\right)$ of sodium nitrite. Results were expressed as $\mathrm{mmol} / \mathrm{mg}$ protein of nitrates plus nitrites [24].

\subsection{Determination of Antioxidant Enzyme Activities}

Superoxide dismutase (SOD) activity, expressed as units per milligram of protein, was based on the inhibition of superoxide radical reaction with pyrogallol [25]. Catalase (CAT) activity was determined by following the decrease in hydrogen peroxide $\left(\mathrm{H}_{2} \mathrm{O}_{2}\right)$ absorbance at $240 \mathrm{~nm}$. It was expressed as nanomol of $\mathrm{H}_{2} \mathrm{O}_{2}$ reduced per minute per milligram of protein [26]. Glutathione-S-transferase activity, expressed as nanomols per minute per milligram of protein, was measured by the rate of formation of dinitrophenyl-S-glutathione at $340 \mathrm{~nm}$ [27]. 


\subsection{Tert-Butyl Hydroperoxide-Initiated Chemiluminescence}

Chemiluminescence was measured in a liquid scintillation counter in the out-of-coincidence mode (LKB Rack Beta Liquid Scintillation Spectrometer 1215, LKB-Produkter AB, Sweden). Homogenates were placed in lowpotassium vials at a protein concentration of $0.5-1.0 \mathrm{mg} / \mathrm{mL}$ in a reaction medium consisting of $120 \mathrm{mmol} / \mathrm{L}$ $\mathrm{KCl}, 30 \mathrm{mmol} / \mathrm{L}$ phosphate buffer $(\mathrm{pH}=7.4)$. Measurements were started by the addition of $3 \mathrm{mmol} / \mathrm{L}$ tert-butyl hydroperoxide, and data are expressed as counts per second per milligram of protein of the homogenates (cps/mg protein).

\subsection{Determination of Protein Concentration}

Protein was measured by the method of Lowry et al. [28], using bovine serum albumin as the standard.

\subsection{Statistical Analysis}

Data were expressed as mean values and standard error of mean (SEM) and were compared by using two-way analysis of variance. The post-hoc Bonferroni test was used to determine significant differences among individual groups. Values were considered significant when $P<0.05$. Statistical analysis was performed using the SPSS 17.6 software.

\section{Results}

Typical signs of diabetes were achieved as can be seen in Table 1, where glycemia was increased in diabetic groups compared with their controls. The ISP diet was able to reduce glycemia in the $\mathrm{D}+\mathrm{S}$ group compared with the D + C (reduction of 21\%), but this value was still higher than control treatment. The average food consumption in diabetic groups was significantly higher than the control $(43 \%$ and $47 \%$, D + C and D + S respectively). Diabetic rats have also shown a decreased body weight compared with the control (38\% and $44 \%)$. The heart weight was decreased in the $\mathrm{D}+\mathrm{C}$ and $\mathrm{D}+\mathrm{S}$ groups compared with control Heart to body weight ratio was no different among diabetic groups compared with the control group.

Table 2 presents the antioxidant enzyme activities in the heart homogenates. SOD activity was significantly increased in D + S when compared to D + C (48\%). A significantly decrease was found in CAT activity when D + C (57\%) and D + S (65\%) was compared with control. GST activity, while the D + S group had a significant increase (52\%) compared with D + C.

Figure 1 demonstrates total nitrates and lipid peroxidation. Myocardial concentration of nitrates $(\mu \mathrm{mol} / \mathrm{mg}$ prot) was increased in $\mathrm{D}+\mathrm{S}(1.40 \pm 0.24)$ compared with $C$ group $(0.62 \pm 0.10)$, being no statistically significant when comparing with $\mathrm{D}+\mathrm{C}$ group $(0.91 \pm 0.15)$. The lipid peroxidation, evaluated by tert-butyl hydroperoxide-initiated chemiluminescence, was not different (207 \pm 55 ; $212 \pm 55$ and $255 \pm 14$ ) among the experimental groups.

\section{Discussion and Conclusions}

The major findings of the present study were that glycemia decreased in diabetics rats, NO metabolites incr-

Table 1. Glycemia, Chow consumption, Body weight, Heart weight, Heart/body Weight ratio in experimental groups.

\begin{tabular}{|c|c|c|c|c|}
\hline Parameters groups & $\mathrm{C}$ & $\mathrm{D}+\mathrm{C}$ & $D+S$ & $P$-value \\
\hline Glycemia (mg/dL) & $102 \pm 3$ & $461 \pm 30^{b}$ & $362 \pm 25^{d}$ & 0.002 \\
\hline Chow consumption (g/week) & $241 \pm 16$ & $344 \pm 24^{\mathrm{c}}$ & $355 \pm 20^{b}$ & 0.002 \\
\hline BW (g) & $345 \pm 19$ & $212 \pm 18^{b}$ & $192 \pm 8^{c}$ & $<0.0001$ \\
\hline $\mathrm{HW}$ (mg) & $1153 \pm 37$ & $924 \pm 59^{d}$ & $783 \pm 50^{b}$ & 0.0007 \\
\hline HW/BW (mg/g) & $3.50 \pm 0.20$ & $4.06 \pm 0.30$ & $4.20 \pm 0.10$ & 0.09 \\
\hline
\end{tabular}

Body weight (BW) and heart weight (HW). The data appear as the mean \pm SEM $(n=5)(P<0.05$, two-way ANOVA, followed by the Tukey post hoc test). $\mathrm{C}=$ casein; $\mathrm{D}+\mathrm{C}=$ diabetic + casein; $\mathrm{D}+\mathrm{S}=$ diabetic + soy. ${ }^{\mathbf{a}, \mathbf{b}, \mathbf{c}}$ Means with the same letter in the same raw into each parameter are not significantly. 
Table 2. Antioxidant defenses in heart homogenates of experimental groups.

\begin{tabular}{ccccc}
\hline Parameters & C & D + C & D + S & $P$ \\
\hline SOD (U/mg prot) & $22.2 \pm 4.2$ & $13.3 \pm 1.0$ & $19.7 \pm 2.2^{\mathrm{b}}$ & 0.02 \\
CAT (nmol/mg prot) & $170 \pm 34$ & $72 \pm 14^{\mathrm{a}}$ & $60 \pm 9^{\mathrm{b}}$ & 0.007 \\
GST (nmol/mg prot) & $10.0 \pm 0.5$ & $23.0 \pm 0.2^{\mathrm{a}}$ & $35.0 \pm 1.1^{\mathrm{b}}$ & $<0.0001$ \\
\hline
\end{tabular}

Superoxide dismutase (SOD), catalase (CAT) and glutathione S-transferase (GST). The data appear as the mean \pm SEM ( $\mathrm{n}=5$ ) two-way ANOVA, followed by the Tukey post hoc test). ${ }^{\mathbf{a}, \mathbf{b}, \mathbf{c}}$ Means with the same letter in the same raw into each parameter are not significantly

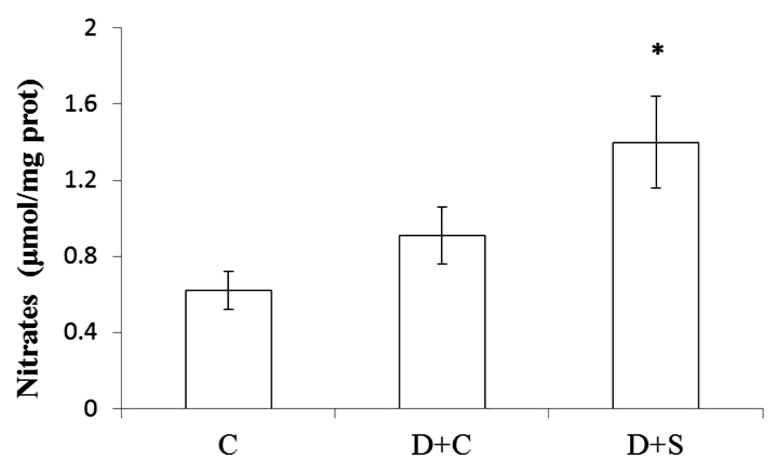

(a)

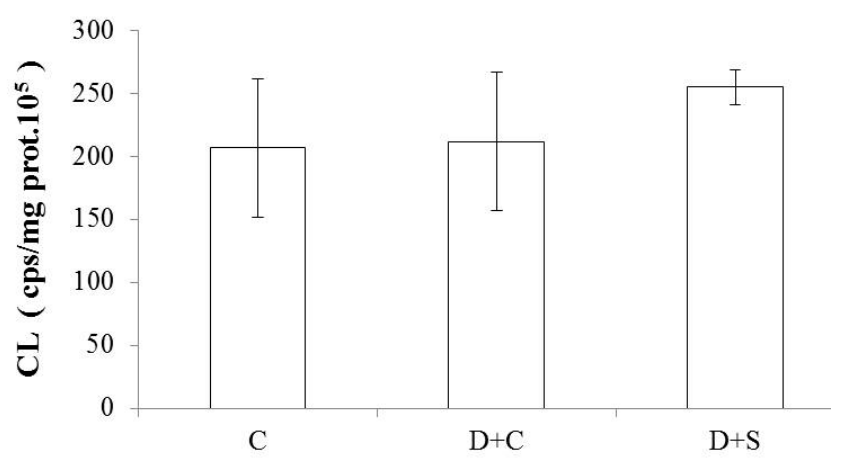

(b)

Figure 1. (a) Effects of 3 weeks of dietary treatment on the concentration of nitrates in heart homogenates $(P=0.02)$. (b) Levels of lipid peroxidation in heart homogenates after treatment. Values are expressed as mean \pm SEM (5 animals/group) $(P=0.72)$, two-way ANOVA, followed by the Bonferroni post hoc test. $\mathrm{C}=$ casein; $\mathrm{D}+\mathrm{C}=\operatorname{diabetic}+$ casein; $\mathrm{D}+\mathrm{S}=$ diabetic + soy; ${ }^{*}$ vs $C ;{ }^{* *}$ vs D + C.

eased in diabetic rats and diabetic rats presented antioxidant profile amelioration measured by antioxidant enzymes activities after ISP-based diet administration. These findings imply that the ISP -based diet might ameliorate the life quality of diabetic patients during treatment.

Initially, the induction of diabetes by STZ is the most used model for induce diabetes in mice or rats because show similar signs of diabetes in humans. This model of diabetes is frequently utilized to study diabetes and its complications. The usually symptoms of this model are elevation in plasma glucose levels, reduction in body weight, and increase in food intake. In our study we found hyperglycemia, weight loss and increased of food intake in diabetic groups. The results about the STZ model were confirm in preliminary findings of our group [29]-[31].

It's well described that type 1 diabetes results from destruction of the majority of the pancreatic beta cells, therefore expansion of the $\beta$ cell mass is possible approach to its treatment [32]. Our data indicated a therapeutic effect of the ISP-based diet in the reducing glycemia in the D + S group compared with D + C, suggesting an ISP diet hypoglycemic effect. The phytoestrogen genistein and your beneficial effects on glycemic control are still unclear. The isoflavones might directly intervene in the activity of some enzymes involved on glycemic 
control such as $\alpha$-glucosidase and tyrosine kinase [33].

ISP-based diet begun 7 days after diabetes induction, because in the soy composition a high L-arginine amino acid concentration is found that may promote increased insulin secretion [34]. This hypothesis was demonstrated by Lu et al. [35] who investigated diabetic male Sprague-Dawley rats with a diet supplemented with isoflavones and observed a significant increase in insulin secretion. In fact, this effect could be due to the insulinotropic substances present in soy fractions, which induce protection of the functional $\beta$ cells from further deterioration.

In terms of antioxidant enzyme activities, our results show that SOD activity was significantly increased in D + S. In agreement with our findings, another study of our group showed that SOD activity increased in rats sham-infarcted fed with ISP [21]. A preliminary study demonstrated a decrease in SOD activity in the liver of STZ-diabetic animals compared to the controls, but when genistein and ISP was administrated, the enzyme activity increased [36]. The SOD activity might be induced by ISP diet and the inhibition of the ROS generation and important regulatory effect on nitric oxide provoked by genistein [37].

GST is one of the enzymes that help the body to detoxify from products of oxidative metabolism. Another study investigated the effect of genistein supplementation in Nrf2 that in oxidative stress state is separated of keap1 and translocated to the nucleus. It activates enzymes such as heme-oxigenase-1 (HO-1), NADH (H), quinolone oxidoreductase-1(NQO-1) and GSH-Px (glutathione peroxidase). The results are reverted by genistein supplementation, supporting the hypothesis that genistein reestablish the cell homeostasis [38] [39]. This result is in agreement with us, because the increase of GST activity in D + S group may be reflecting the detoxify process in this experimental group.

Our results indicate that CAT activity, a specific enzyme to decompose $\mathrm{H}_{2} \mathrm{O}_{2}$, is decreased in D + C and D + $\mathrm{S}$ compared with control, showing that ISP-based diet might not altered CAT metabolism. In disagreement with our results, another study using soybean supplementation for 4 weeks in diabetics 2 subjects showed that CAT activity, evaluated in blood, was higher after supplementation period [40]. This result may suggest that ISPbased diet not influence CAT metabolism in this experimental protocol.

Besides ROS, we evaluated the metabolism of nitric oxide by nitrates concentration. A previous study demonstrated that in menopausal women the soy isoflavone had no effect on nitric oxide metabolism [40]. Another study showed that soy protein seemed to be effective improving NO generation in renal system of obese Zucker rats [40]. However, it is important to highlight that NO bioavaibility is diminished in insulin resistance. We observed that the NO metabolites were increased after ISP administration [39]. This result suggested the role of ISP-based diet ameliorating the NO bioavaibility and protecting the cardiovascular system.

In relation to lipid peroxidation, we did not observe differences among experimental groups. Diabetic animals generally present increased production and liberation into the circulation of lipid peroxides due to pathological changes [36]. This result may indicate that the antioxidant enzymes modulation in this experimental protocol is resulting in a transient compensatory mechanism by the body in an attempt to neutralize the ROS production.

In summary, the findings of the present study demonstrate that an ISP diet ameliorates the glycemia associated with modulation of the SOD and GST profile, and NO bioavailability. Collectively, our results reinforce the role of ISP as an antioxidant and a useful strategy to help the treatment of diabetes.

\section{References}

[1] Gilbert, E.R. and Liu, D. (2013) Anti-Diabetic Functions of Soy Isoflavone Genistein: Mechanisms Underlying Its Effects on Pancreatic Beta-Cell Function. Food \& Function, 4, 200-212. http://dx.doi.org/10.1039/c2fo30199g

[2] Zatalia, S.R. and Sanusi, H. (2013) The Role of Antioxidants in the Pathophysiology, Complications, and Management of Diabetes Mellitus. Acta medica Indonesiana, 45, 141-147.

[3] Huebschmann, A.G., Regensteiner J.G., Vlassara H. and Reusch J.E. (2006) Diabetes and Advanced Glycoxidation End Products. Diabetes Care, 29, 1420-1432. http://dx.doi.org/10.2337/dc05-2096

[4] Ceriello, A. (2003) New Insights on Oxidative Stress and Diabetic Complications May Lead to a "Causal” Antioxidant Therapy. Diabetes Care, 26, 1589-1596. http://dx.doi.org/10.2337/diacare.26.5.1589

[5] Anwar, M.M. and Meki, A.R. (2003) Oxidative Stress in Streptozotocin-Induced Diabetic Rats: Effects of Garlic Oil and Melatonin. Comparative Biochemestry and Physiolology: A Molecular and Integrative Physiology, 135, 539-547.

[6] Wolff, S.P. and Dean, R.T. (1987) Glucose Autoxidation and Protein Modification. The Potential Role of "Autoxidative Glycosylation” in Diabetes. Biochemestry Journal, 245, 243-250.

[7] Coskun, O., Kanker, M., Korkmaz, A., Oter, S. (2005) Quercetin, a Flavonoid Antioxidant, Prevents and Protects Stre- 
ptozotocin-Induced Oxidative Stress and Beta-Cell Damage in Rat Pancreas. Pharmacology Research, 51, 117-123. http://dx.doi.org/10.1016/j.phrs.2004.06.002

[8] Kumar, S., Prasad, S. and Sitasawad, S.L. (2013) Multiple Antioxidants Improve Cardiac Complications and Inhibit Cardiac Cell Death in Streptozotocin-Induced Diabetic Rats. PLoS One, 8, e67009.

http://dx.doi.org/10.1371/journal.pone.0067009

[9] Heneman, K.M., Chang, H.C., Prior, R.L. and Steinberg, F.M., (2007) Soy Protein with and without Isoflavones Fails to Substantially Increase Postprandial Antioxidant Capacity. Journal of Nutritional Biochemistry, 18, 46-53. http://dx.doi.org/10.1016/j.jnutbio.2006.03.001

[10] Klepac, N., Rudes, Z. and Klepac, R. (2006) Effects of Melatonin on Plasma Oxidative Stress in Rats with Streptozotocin Induced Diabetes. Biomedicine and Pharmacotherapy Journal, 60, 32-35. http://dx.doi.org/10.1016/j.biopha.2005.08.005

[11] Kowluru, R.A., Abbas, S.N. and Odenbach, S. (2004) Reversal of Hyperglycemia and Diabetic Nephropathy: Effect of Reinstitution of Good Metabolic Control on Oxidative Stress in the Kidney of Diabetic Rats. Journal of Diabetes Complications, 18, 282-288. http://dx.doi.org/10.1016/j.jdiacomp.2004.03.002

[12] Erdman Jr., J.W. (2000) AHA Science Advisory: Soy Protein and Cardiovascular Disease: A Statement for Healthcare Professionals from the Nutrition Committee of the AHA. Circulation, 102, 2555-2559. http://dx.doi.org/10.1161/01.CIR.102.20.2555

[13] Omoni, A.O. and Aluko, R.E. (2005) Soybean Foods and Their Benefits: Potential Mechanisms of Action. Nutrition Reviews, 63, 272-283. http://dx.doi.org/10.1111/j.1753-4887.2005.tb00141.x

[14] Reinwald, S. and Weaver, C.M. (2010) Soy Components vs. Whole Soy: Are We Betting Our Bones on a Long Shot? Journal of Nutrition, 140, 2312S-2317S. http://dx.doi.org/10.3945/jn.110.124008

[15] Patel, R.P., Boersma, B.J., Crawford, J.H., Hogg, N., Kirk, M., Kalyanaraman, B., Parks, D.A., Barnes, S. and Darley-Usmar, V. (2001) Antioxidant Mechanisms of Isoflavones in Lipid Systems: Paradoxical Effects of Peroxyl Radical Scavenging. Free Radical Biology and Medicine, 31, 1570-1581. http://dx.doi.org/10.1016/S0891-5849(01)00737-7

[16] Wiegand, H., Wagner, A.E., Boesch-Saadatmandi, C., Kruse, H.P., Kulling, S. and Rimbach, G. (2009) Effect of Dietary Genistein on Phase II and Antioxidant Enzymes in Rat Liver. Cancer Genomics Proteomics, 6, 85-92.

[17] Barnes, S. (1995) Effect of Genistein on in Vitro and in Vivo Models of Cancer. Journal of Nutrition, 125, 777S-783S.

[18] Stauffer, C.E. (2005) Soy Protein in Baking. 2nd Edition, Technical Foods Consultants, Cincinnati.

[19] Hagen, M.K., Ludke, A., Araujo, A.S., Mendes, R.H., Fernandes, T.G., Mandarino, J.M., Llesuy, S., Vogt de Jong, E. and Belló-Klein, A. (2012) Antioxidant Characterization of Soy Derived Products in Vitro and the Effect of a Soy Diet on Peripheral Markers of Oxidative Stress in A Heart Disease Model. Canadian Journal of Physiology and Pharmacology, 90, 1095-1103. http://dx.doi.org/10.1139/y2012-028

[20] Junod, A., Lambert, A.E., Orci, L., Pictet, R., Gonet, A.E. and Renold, A.E. (1967) Studies of the Diabetogenic Action of Streptozotocin. Proceedings of the Society for Experimental Biology and Medicine, 126, 201-205. http://dx.doi.org/10.3181/00379727-126-32401

[21] Hagen, M.K., Lehenbauer-Lüdke, A.R., Paludo, A.C., Schenkel, P., Gonçalves, L., Fernandes, T.G., Caron, R., Llesuy, S., Mill, J.G. and Belló-Klein, A. (2009) Diet with Isolated Soy Protein Reduces Oxidative Stress and Preserves Ventricular Function in Rats with Myocardial Infarction. Nutrition Metabolism and Cardiovascular Disease, 19, 91-97. http://dx.doi.org/10.1016/j.numecd.2008.03.001

[22] Reeves, P.G., Nielsen, F.H. and Fahey Jr. G.C. (1993) AIN-93 Purified Diets for Laboratory Rodents: Final Report of the American Institute of Nutrition Ad Hoc Writing Committee on the Reformulation of the AIN-76A Rodent Diet. Journal of Nutrition, 123, 1939-1951.

[23] da Rosa Araujo, A.S., Silva de Miranda, M.F., de Oliveira, U.O., Fernandes, T., Llesuy, S., Rios Kucharski, L.C., Khaper, N. and Belló-Klein, A. (2010) Increased Resistance to Hydrogen Peroxide-Induced Cardiac Contracture Is Associated with Decreased Myocardial Oxidative Stress in Hypothyroid Rats. Cell Biochemestry and Function, 28, 3844. http://dx.doi.org/10.1002/cbf.1616

[24] Granger, D.L., Anstey, N.M., Miller, W.C. and Weinberg, J.B. (1999) Measuring Nitric Oxide Production in Human Clinical Studies. Methods Enzymology, 301, 49-61. http://dx.doi.org/10.1016/S0076-6879(99)01068-X

[25] Marklund, S. and Marklund, G. (1974) Involvement of the Superoxide Anion Radical in the Autoxidation of Pyrogallol and a Convenient Assay for Superoxide Dismutase. European Journal of Biochemestry, 47, 469-474. http://dx.doi.org/10.1111/j.1432-1033.1974.tb03714.x

[26] Aebi, H. (1984) Catalase in Vitro. Methods Enzymology, 105, 121-126. http://dx.doi.org/10.1016/S0076-6879(84)05016-3 
[27] Gonzalez Flecha, B., Llesuy, S. and Boveris, A. (1991) Hydroperoxide-Initiated Chemiluminescence: An Assay for Oxidative Stress in Biopsies of Heart, Liver and Muscle. Free Radical Biology and Medicine, 10, 93-100. http://dx.doi.org/10.1016/0891-5849(91)90002-K

[28] Lowry, O.H., Rosebrough, N.J., Farr, A.L. and Randall, R.J. (1951) Protein Measurement with the Folin Phenol Reagent. Journal of Biological Chemistry, 193, 265-275.

[29] Schaan, B.D., Dall’Ago, P., Maeda, C.Y., Ferlin, E., Fernandes, T.G., Schmid, H. and Irigoyen, M.C. (2004) Relationship between Cardiovascular Dysfunction and Hyperglycemia in Streptozotocin-Induced Diabetes in Rats. Brazilian Journal of Medical Biological Research, 37, 1895-1902. http://dx.doi.org/10.1590/S0100-879X2004001200016

[30] Wichi, R., Malfitano, C., Rosa, K., De Souza, S.B., Salemi, V., Mostarda, C., De Angelis, K. and Irigoyen, M.C. (2007) Noninvasive and Invasive Evaluation of Cardiac Dysfunction in Experimental Diabetes in Rodents. Cardiovascular Diabetology, 6, 14. http://dx.doi.org/10.1186/1475-2840-6-14

[31] Dias, L.D., Casali, K.R., Leguisamo, N.M., Azambuja, F., Souza, M.S., Okamoto, M., Machado, U.F., Irigoyen, M.C. and Schaan, B.D. (2011) Renal Denervation in an Animal Model of Diabetes and Hypertension: Impact on the Autonomic Nervous System and Nephropathy. Cardiovascular Diabetology, 10, 33. http://dx.doi.org/10.1186/1475-2840-10-33

[32] Shin, S., Li, N., Kobayashi, N., Yoon, J.W. and Jun, H.S. (2008) Remission of Diabetes by Beta-Cell Regeneration in Diabetic Mice Treated with a Recombinant Adenovirus Expressing Betacellulin. Molecular Therapy, 16, 854-861. http://dx.doi.org/10.1038/mt.2008.22

[33] Villa, P., Costantini, B., Suriano, R., Perri, C., Macrì, F., Ricciardi, L., Panunzi, S. and Lanzone, A. (2009) The Differential Effect of the Phytoestrogen Genistein on Cardiovascular Risk Factors in Postmenopausal Women: Relationship with the Metabolic Status. Journal of Clinical Endocrinology and Metabolism, 94, 552-558. http://dx.doi.org/10.1210/jc.2008-0735

[34] Adeghate, E., Ponery, A.S., El-Sharkawy, T. and Parvez, H. (2001) L-Arginine Stimulates Insulin Secretion from the Pancreas of Normal and Diabetic Rats. Amino Acids, 21, 205-209. http://dx.doi.org/10.1007/s007260170028

[35] Lu, M.P., Wang, R., Song, X., Chibbar, R., Wang, X., Wu, L. and Meng, Q.H. (2008) Dietary Soy Isoflavones Increase Insulin Secretion and Prevent the Development of Diabetic Cataracts in Streptozotocin-Induced Diabetic Rats. Nutrition Research, 28, 464-471. http://dx.doi.org/10.1016/j.nutres.2008.03.009

[36] Lee, J.S. (2006) Effects of Soy Protein and Genistein on Blood Glucose, Antioxidant Enzyme Activities and Lipid Profile in Streptozotocin-Induced Diabetic Rats. Life Sciences, 79, 1578-1584. http://dx.doi.org/10.1016/j.lfs.2006.06.030

[37] Maulik, S.K., Prabhakar, P., Dinda, A.K. and Seth, S. (2012) Genistein Prevents Isoproterenol-Induced Cardiac Hypertrophy in Rats. Canadian Journal Physiology Pharmacology, 90, 1117-1125.

[38] Kim, M.J. and Lim, Y. (2013) Protective Effect of Short-Term Genistein Supplementation on the Early Stage in Diabetes-Induced Renal Damage. Mediators Inflammation, 2013, Article ID: 510212. http://dx.doi.org/10.1155/2013/510212

[39] Wang, F., Tian, F., Whitman, S.A., Zhang, D.D., Nishinaka, T., Zhang, N. and Jiang, T. (2012) Regulation of Transforming Growth Factor Beta1-Dependent Aldose Reductase Expression by the Nrf2 Signal Pathway in Human Mesangial Cells. European Journal of Cell Biology, 91, 774-781. http://dx.doi.org/10.1016/j.ejcb.2012.07.004

[40] Wong, W.W., Taylor, A.A., Smith, E.O., Barnes, S. and Hachey, D.L. (2012) Effect of Soy Isoflavone Supplementation on Nitric Oxide Metabolism and Blood Pressure in Menopausal Women. American Journal of Clinical Nutrition, 95, 1487-1494. http://dx.doi.org/10.3945/ajcn.111.032045 
Scientific Research Publishing (SCIRP) is one of the largest Open Access journal publishers. It is currently publishing more than 200 open access, online, peer-reviewed journals covering a wide range of academic disciplines. SCIRP serves the worldwide academic communities and contributes to the progress and application of science with its publication.

Other selected journals from SCIRP are listed as below. Submit your manuscript to us via either submit@scirp.org or Online Submission Portal.
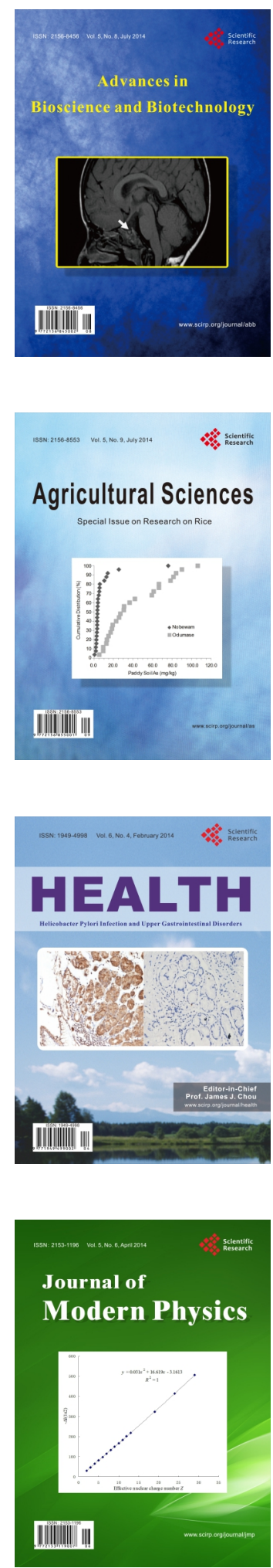
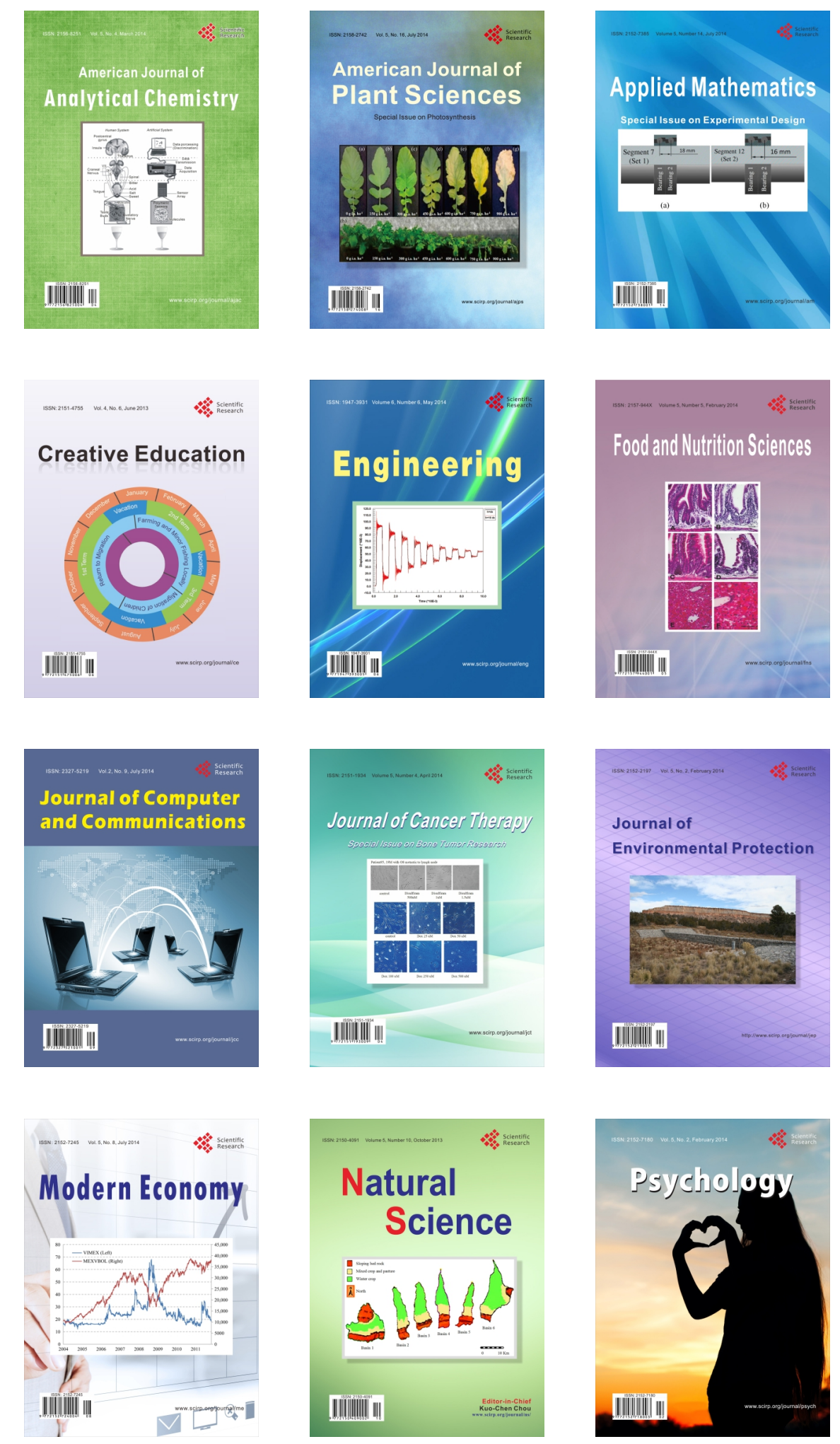